\title{
Implications Of Mixed Results With Cointegration Models In International Studies
}

Hatem Al-Shanfari (E-mail: hatem@squ.edu.om), Sultan Qaboos University, Sultanate of Oman Paul Sheldon Foote (E-mail: pfoote@fullerton.edu), California State University, Fullerton

\begin{abstract}
While cointegration models have been used extensively in many fields (such as in testing for stock market predictability), there have been mixed results from using cointegration models in international studies. For example, one study attempted to regress the levels of the general stock market price indexes of Norway, Mexico, Venezuela, and of Oman on the levels of interest rate and oil prices variables during the period 1992 to 1999. Attempts to explain mixed results have included distinguishing developed markets versus less developed markets and differences in the volatilities of markets. Another approach has been attempts to improve cointegration methods. Some studies have included both bivariate and multivariate methods of cointegration. Others have employed augmented Dickey-Fuller unit root tests of the residuals. The extent of mixed results in international studies has implications for earlier studies in single countries. It is possible that many earlier studies in business and in economics will need to be replicated using newer techniques developed by international researchers. The purpose of this study is to explain the attempts to improve cointegration methods, the mixed results in international studies, and the implications for earlier studies relying upon cointegration models.
\end{abstract}

\section{Introduction}

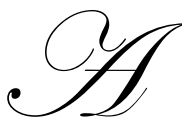

problem with econometric methods has been that some of the individual variables in economic models can be non-stationary (wildly behaving). Since Granger (1981), there have been attempts to use cointegration to find stationary (nicely behaved) relationships between non-stationary variables. One goal of this approach has been to achieve superior explanatory models by reducing spurious relationships between variables. Another goal has been to produce superior forecasts over long horizons using structurally superior models.

Over the last two decades, there have been many studies involving the use of cointegration to find long-run determinants in many fields, such as real exchange rates and long-term gains from internationally diversified stock portfolios. However, international cointegration studies include frequently mixed results. For example, there could be significant evidences of cointegration in the data from some, but not all, countries in the same research study. A review of some of the international cointegration studies with mixed results may have implications for earlier studies in many fields based upon findings of significant evidence of cointegration.

\section{Testing The Arbitrage Pricing Theory In The Global Context}

Al-Shanfari (2001) used cointegration methods in testing the arbitrage pricing theory on 8 years (1992 1999) of time series data for 5 net oil exporting countries: Mexico, Norway, Oman, United Kingdom, and Venezuela. According to the Arbitrage Pricing Theory, there should be some systematically significant factors in determining asset returns in efficient markets. It should be possible to observe some variables commanding risk premi ums in stock markets.

Readers with comments or questions are encouraged to contact the authors via email. 
In studies involving a single stock market in a single country, researchers have suggested some variables are significantly priced. In studies involving the data from stock markets in several countries over the same time horizon, it is possible that the same sets of variables will not be significantly priced and that cointegration methods may have mixed results in predicting returns.

To test the return predictability form of efficient market hypothesis, Al-Shanfari (2001) attempted to regress the levels of the general stock market price indexes of Norway, Mexico, Venezuela and Oman on the level of interest rate and oil prices variables during 1992 to 1999. The levels of stock market price indices and the two observed variables were nonstationary. There were mixed regression results. The share prices could not be predicted using interest rate and oil prices variables for Mexico, Norway, Oman, and for the United Kingdom.. Share prices could be predicted using interest rate and oil prices variables for Venezuela because there was some cointegration..

\section{Efficient Markets}

Are stock markets efficient in factoring publicly available information at all times? It maybe is possible to state that the stock markets are neither at all times efficient or inefficient. Generally, stock markets, when not experiencing boom or bust, tend to be efficient in rapidly reflecting the available public information. The degree of efficiency is relatively higher in developed stock markets in comparison to the developing ones. Stock market inefficiency tends to be greatest during periods of speculative bubbles when share prices are highly volatile.

Tests of return predictability of the efficient market hypothesis are intended to verify whether expected returns can be forecasted using past returns and/or other fundamental variables, like dividend yield, interest rate and oil prices (see Clare and Thomas (1992), Ferson and Harvey (1993, 94 and 98), MacDonald (1994) and Shiller (1981 and 97)). According to the efficient market hypothesis, the expected returns of listed shares are not predictable because current prices reflect all publicly available information. As a result, market participants will not be able to use historical information or any other current information that is in the public domain to successfully predict their future behaviour and hence, achieve above average rate of returns (see Fama, 1970). Furthermore, since the efficient market hypothesis states that returns are not predictable, this means that trading strategies based on using historical data to earn above average returns, such as using technical analysis methods, are not appropriate.

Empirical tests of return predictability used fundamental variables in forecasting future returns. Clare, Priestley and Thomas (1997) investigated the predictability of returns in Germany, Japan, the UK and the USA using monthly time series data for the period 1981 to 1993. They regressed the excess return on the four countries stock market indexes on the dividend yield, term structure of interest rate, interest rate variables plus a dummy variable. The authors obtained mixed results for the four countries. While the German and Japan stock indexes were not predictable, which points to the existence of an efficient market, the UK and the USA data showed some sort of predictability in stock market indices.

Furthermore, MacDonald and Power (1994) used the cointegration method to test the efficient market hypothesis in the UK stock market using weekly series in the period from January 1982 to June 1990. The authors tested the possibility of cointegration between twenty-five listed companies and the FT all share index. They used both bivariate and multivariate methods of cointegration and concluded that in the case of bivariate cointegration tests, there was an indication of market efficiency. But when the multivariate method of cointegration was used, there was an indication of market inefficiency because the null hypothesis of no cointegration was rejected in favour of cointegration between the market index and the twenty-five listed companies in the London Stock Exchange.

Even for the developing stock markets, Harvey (1995) conducted a study on the predictability of returns in developing stock markets that included twenty countries ${ }^{1}$. He used monthly time series data from March 1986 to June 1992 and concluded that developing stock markets are more predictable than developed markets based on regression analysis.

The twenty developing stock markets are; Argentina, Brazil, Chile, Colombia, Greece, India, Indonesia, Jordan, Korea, Malaysia, Mexico, Nigeria, Pakistan, Philippines, Portugal, Taiwan, Thailand, Turkey, Venezuela and Zimbabwe. 
From different empirical results which used daily, weekly and monthly time series to test the market efficiency in both developed and developing stock markets, it is possible to state that there is generally sufficient empirical evidence which contradict the notion of market efficiency. Fama (1991) acknowledges that return predictability tests have caused controversy about market efficiency.

\section{Cointegration Models}

The principle of cointegration technique is based on having two or more series of data that have nonstationary levels but have stationary first differences. Such series would be known to have first order of integration; i.e. I (1). The order of integration can be verified by using augmented Dickey-Fuller (ADF) unit root tests (see Engle and Granger (1991) and Harris (1995). It is now common when determining the order of integration or testing the stationarity of a time-series data to use Dickey-Fuller (DF) unit root tests, which are based on the following two equations:

$$
\begin{aligned}
& \Delta \mathrm{Zt}=\alpha 1+\beta \mathrm{Zt}-1+\mathrm{ut} \\
& \Delta \mathrm{Zt}=\alpha 1+\alpha 2 \mathrm{t}+\beta \mathrm{Zt}-1+\mathrm{ut}
\end{aligned}
$$

The values of the $t$ statistic for the $\beta$ coefficient in the above Equations are known as $\tau$ statistic. The critical values of $\tau$ have been computed by Dickey and Fuller (1979 and 1981) based on Monte Carlo simulation experiments. The $\tau$ test is known as DF statistic. When testing the null hypothesis $(\mathrm{H} 0: \beta=0)$ for non-stationary series in (1) and (2) above, if the estimated absolute value of $\tau$ is greater than the DF absolute critical values at the 1\%, 5\% and $10 \%$ level of significance, then we reject the null hypothesis of non-stationarity in favour of stationarity. But if it is less than the critical values, we can not reject the null hypothesis of non-stationarity. When the error term (u t) is serially correlated, in any of the above (1) and (2), then they are modified to remove the serial correlation in the error term by introducing an appropriate number of lagged variables for $\Delta \mathrm{Z} \mathrm{t}$, as is given in equations (3) and (4) below. These are known as the Augmented Dickey-Fuller (ADF) test and have the same critical values as the DF statistic.

$$
\begin{aligned}
& \Delta \mathrm{Zt}=\alpha 1+\beta \mathrm{Zt}-1+\vartheta \mathrm{i} \sum \mathrm{ki}=1 \Delta \mathrm{Zt}-\mathrm{i}+\delta \mathrm{t} \\
& \Delta \mathrm{Zt}=\alpha 1+\alpha 2 \mathrm{t}+\beta \mathrm{Zt}-1+\vartheta \mathrm{i} \sum \mathrm{ki}=1 \Delta \mathrm{Zt}-\mathrm{i}+\delta \mathrm{t}
\end{aligned}
$$

If the level of a time series data is stationary, this means that the series is predictable because it tends to revert to its historic means. Whereas, non-stationary series implies unpredictability. When two or more series which have first order of integration are regressed and their residuals are stationary, then they form a statistical long-run equilibrium relationship. In this case, the null hypothesis of no-cointegration is rejected in favour of cointegration. This means that the dependent series is efficient and accurate in incorporating available public information about its underlying fundamental variable(s).

\section{The Data}

The test for the predictability of returns, we have utilized the data obtained from four stock markets of Norway, Mexico, Venezuela and Oman. The underlying countries are all net exporters of oil which contributes significantly to financing their public sector spending which in turn is expected to stimulate their domestic economic activities. Due to lack of data availability on the dividend yield, we will instead consider interest rate and oil prices variables in order to test the predictability of returns. Therefore, the return predictability test for the four stock markets will be estimated based on each country stock market price index of listed share prices, in local currency, as a function of the main interest rate and oil prices variables. The data under-study is monthly time series data for the period from January 1992 to December 1999. The details of these data sets are given in Al-Shanfari (2001). In these data, the oil prices are measured in US dollars per barrel and is based on the UK Brent crude one-month forward prices. The same benchmark crude oil prices are used for Norway, Mexico, Venezuela and Oman. The one-month forward prices of oil are normally available to the public, so, instead of using the contemporaneous oil prices with the share prices, we have used the one-month forward oil prices. The level and first difference of the oil prices variable are shown in Figure 1 below: 
Figure 1

Oil Prices Variable.

Level



First Difference



The level of the oil prices variable is tested for unit root using the ADF tests to determine its order of integration. If the estimated values of the ADF statistics are greater than their critical values at one, five and ten percents levels of significance, then it is possible to reject the null-hypothesis of non-stationarity in favour of stationarity. Otherwise, the series is expected to be stationary.

Table 1

Unit Root Tests for the Oil Prices Variable.

\begin{tabular}{|l|c|c|}
\hline \multirow{2}{*}{ Variable } & \multicolumn{2}{|c|}{ ADF test * } \\
\cline { 2 - 3 } & Without trend & With Trend \\
\hline Level & -1.96 & -1.82 \\
\hline First Difference & -4.23 & -4.31 \\
\hline
\end{tabular}

* The critical value of the Augmented Dickey-Fuller statistic at $95 \%$ level of significance with intercept $=-2.90$ and with intercept and time trend is $=-3.47$
The estimated ADF - unit root tests for the level and the first difference of the oil prices variable are presented in Table 1. The level of oil prices variable offer to be a nonstationary time series because their estimated absolute values of $\tau$ are less than their critical values, which implies that we cannot reject the null hypothesis for the series to have a unit root; i.e., is nonstationary. Since the ADF unit root test reveals that the level has unit roots, we test its first difference for stationarity.

From the above, it is evident that the ADF tests of the first difference for the oil prices variable that they are all stationary in both cases of ADF unit root tests with and without constant. Therefore, it means that this variable has first order of integration - i.e., it is I (1). 
Figure 2, below, shows the levels and first differences of the interest rate variables for Norway, Mexico, Venezuela and Oman.

Figure 2: Interest Rate Variable.

Level
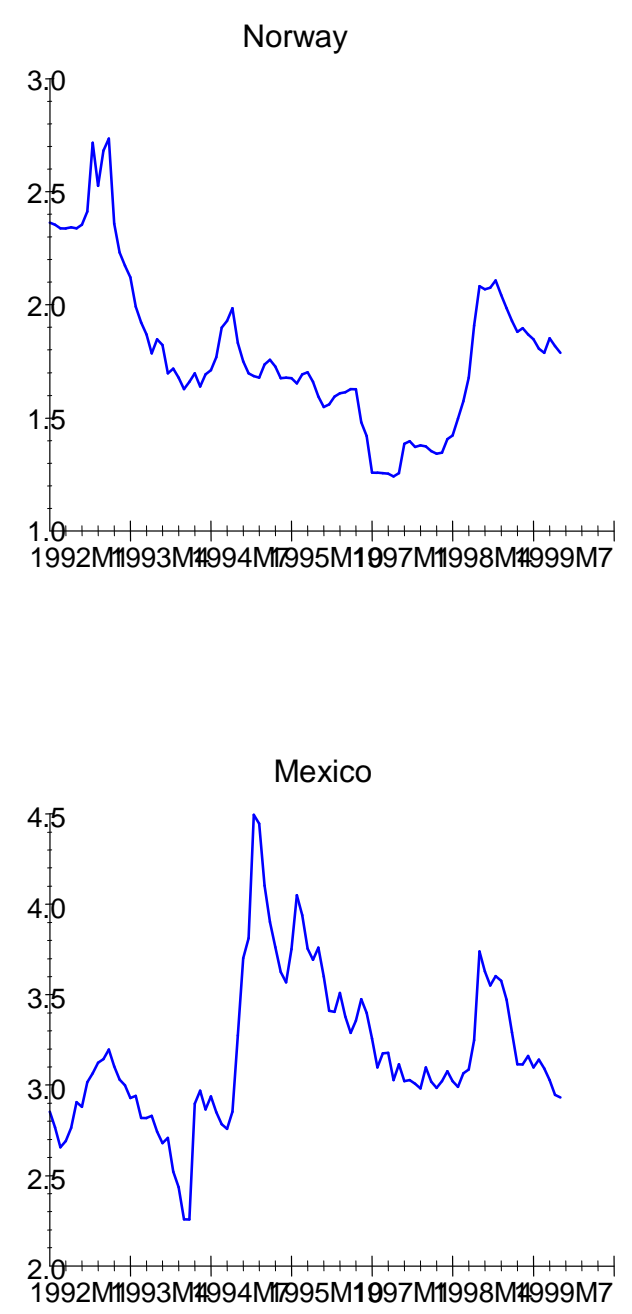

First Difference

Norway
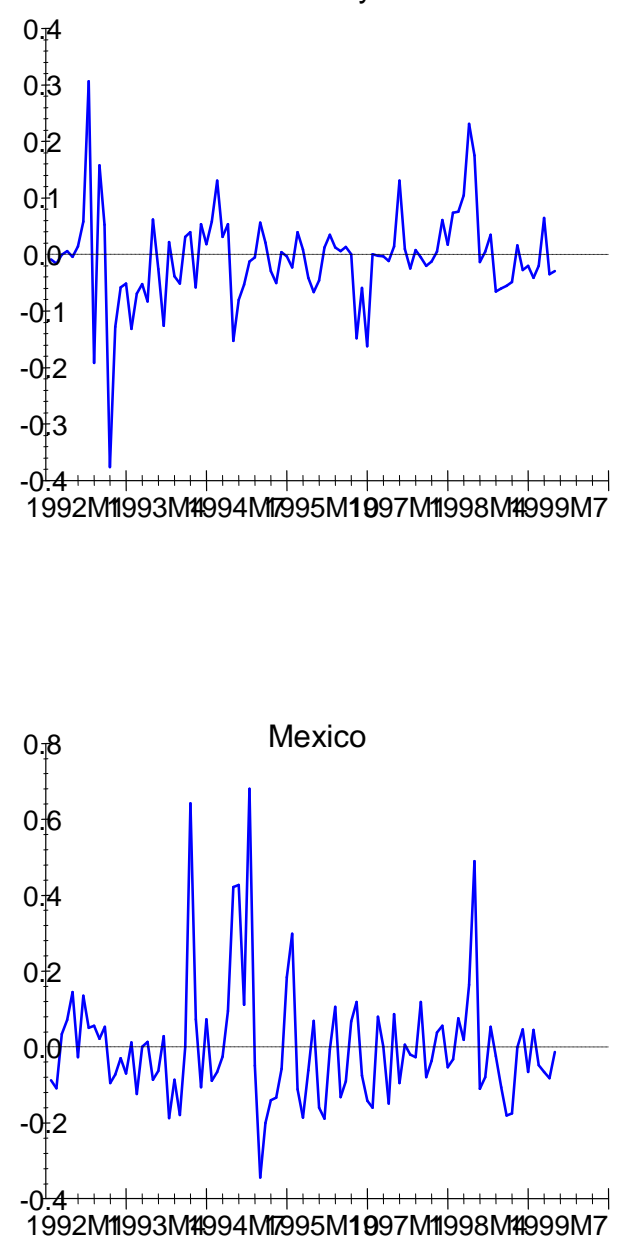
Figure 2 (Cont'd)
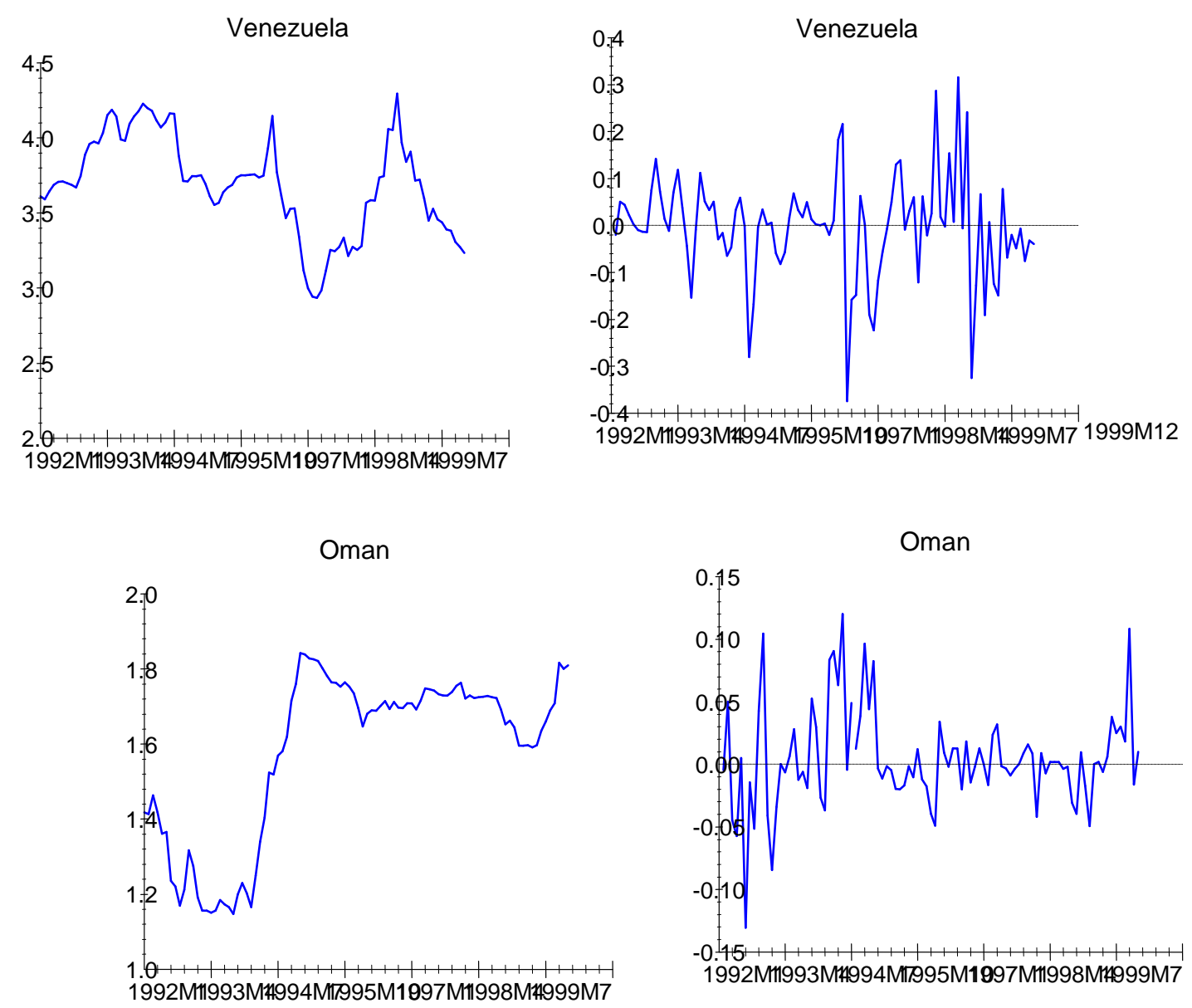

Table 2

Unit Root Tests for the level of the Interest Rate Variables.

\begin{tabular}{|l|c|c|}
\hline \multirow{2}{*}{ Variable } & \multicolumn{2}{|c|}{ ADF test } \\
\cline { 2 - 3 } & Without trend $^{*}$ & With Trend \\
& -2.23 & -2.08 \\
\hline Norway & -2.42 & -2.38 \\
\hline Mexico & -1.66 & -2.20 \\
\hline Venezuela & -2.26 & -2.01 \\
\hline Oman & -2.893 \\
\hline
\end{tabular}

$*$ The critical value for the ADF statistic $=-2.893$

$* *$ The critical value for the ADF statistic $=-3.459$

Table 2 shows the unit root tests for the level of the interest rate variables. It is evident from the table below that the levels of the four variables are not stationary.

Therefore, it is important to test if the first differences of the levels have unit root, as presented in Table 3. Given that the critical calculated ADF - statistics are greater than their critical values, it is possible to state that the interest rate variable in the four countries have first order of integeration. 
Table 3

Unit Root Tests for the first difference of the Interest Rate Variables.

\begin{tabular}{|l|c|c|}
\hline \multirow{2}{*}{ Variable } & \multicolumn{2}{|c|}{ ADF test } \\
\cline { 2 - 3 } & Without trend & With Trend $* *$ \\
\hline Norway & -5.78 & -5.02 \\
\hline Mexico & -2.61 & -2.63 \\
\hline Venezuela & -5.65 & -5.62 \\
\hline Oman & -4.65 & -4.77 \\
\hline
\end{tabular}

$*$ The critical value for the ADF statistic $=-2.893$

$* *$ The critical value for the ADF statistic $=-3.459$
Since we have already determined the order of integration for the interest rate and oil prices variables which are both I (1), we will now determine the order of integration for the Norwegian, Mexican, Venezuelan and Omani stock markets price indexes. Plots of the levels and the rate of returns for the four stock market indexes are shown in Figure 3.

Figure 3: Stock Market Price Indexes: January 1992 - December 1999.

Level

Mexico

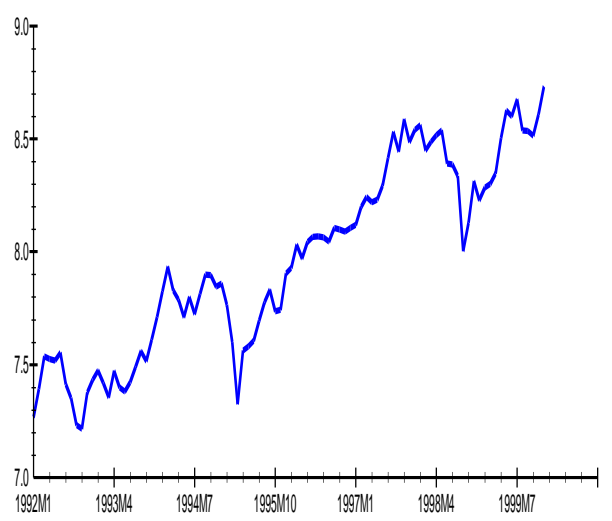

Norway

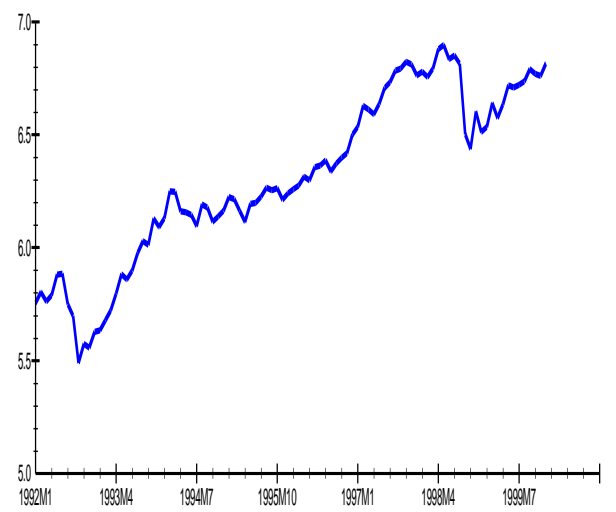

Returns

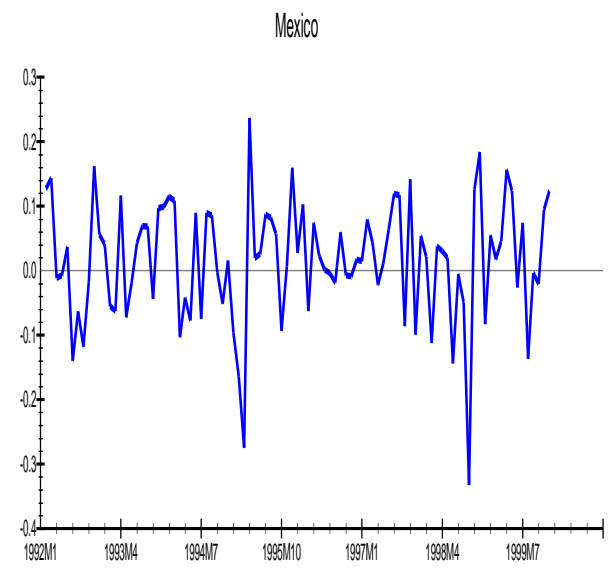

Noway

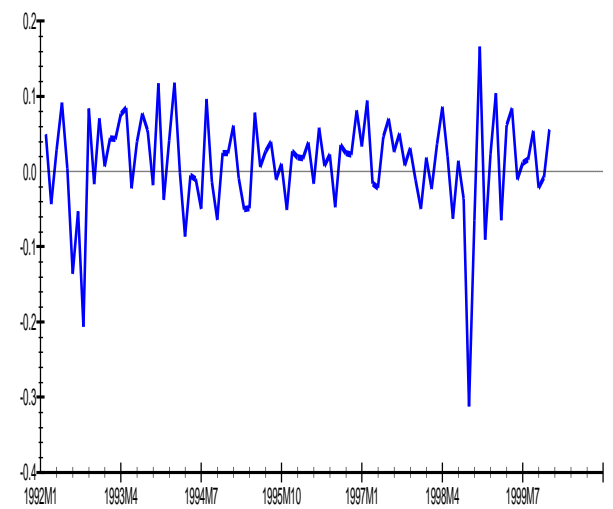


Figure 3 (Cont'd)


The levels of the four stock market price indexes are tested for unit root using the ADF tests to determine their order of integration. The estimated ADF - statistics for the stock market price indexes are tabulated in Table 4 below.

\begin{tabular}{|c|c|c|}
\hline \multicolumn{3}{|c|}{$\begin{array}{c}\text { Table } 4 \\
\text { The Unit Root Tests for the Levels of } \\
\text { Stock Market Price Indexes: } \\
\text { January 1992-December 1999. }\end{array}$} \\
\hline Country & $\begin{array}{c}\text { ADF } \\
\text { without trend * }\end{array}$ & $\begin{array}{c}\text { ADF } \\
\text { with trend ** }\end{array}$ \\
\hline Norway & -2.04 & -2.98 \\
\hline Mexico & -0.84 & -2.81 \\
\hline Venezuela & -1.61 & -1.04 \\
\hline Oman & -1.73 & -2.24 \\
\hline \multicolumn{3}{|c|}{$\begin{array}{l}* \text { The critical value for the ADF statistic }=-2.893 \\
* * \text { The critical value for the ADF statistic }=-3.459\end{array}$} \\
\hline
\end{tabular}

The null-hypothesis of having unit root in the above four cases is not rejected because the estimated ADF - statistics are less than the critical ones. This means that the levels of the stock market price indexes are nonstationary. Since the null-hypotheses of stationarity for the levels are not rejected, the next step is to test if the first differences of the levels which have unit root, as given in Table 5 below. 


\begin{tabular}{|c|c|c|}
\hline \multicolumn{3}{|c|}{$\begin{array}{c}\text { Table } 5 \\
\text { The Unit Root Tests for the First Differences of } \\
\text { Stock Market Composite Price Indexes: } \\
\text { January 1992-December } 1999 .\end{array}$} \\
\hline Country & $\begin{array}{c}\text { ADF } \\
\text { without trend* }\end{array}$ & $\begin{array}{c}\text { ADF } \\
\text { with trend } * *\end{array}$ \\
\hline Norway & -4.21 & -4.27 \\
\hline Mexico & -6.71 & -6.67 \\
\hline Venezuela & -6.28 & -6.47 \\
\hline Oman & -2.73 & -2.80 \\
\hline
\end{tabular}

From Table 5, it is not possible to reject the nullhypothesis of stationarity for the first differences of the price indexes because the estimated DF statistics are greater than their critical values. That means the stock market price indexes for Norway, Mexico, Venezuela and Oman are integrated of the first order; i.e., they are all I (1).

\section{Empirical Results}

Having determined that the order of integration for both the interest rate and the oil prices series and the four stock market price indexes are the same, it is now appropriate to test if the three series are cointegrated, which means that they would form a long-run statistical equilibrium relationship. This can be achieved by regressing the level of the stock market price index ( $\mathrm{P} \mathrm{t}$ ) of each country at a time, on the level of the interest rate ( $\mathrm{I}$ ) and oil prices $(\mathrm{O} \mathrm{t})$ variables, as in Equation (5):

$$
P t=a+b I t+c O t+u t
$$

Testing for cointegration among nonstationary variables that have the same first order of integration is also known in the literature as the tests of predictability. If the regression analysis reveals that the nonstationary variables are cointegrated, this means that dependent variables can be predicted on the basis of the independent variables. Table 6 presents the results from the linear regression analysis for Norway, Mexico, Venezuela and Oman.

Table 6: Regression Analysis of Return Predictability Tests: January 1992- December 1999.

\begin{tabular}{|l|c|c|c|}
\hline \multicolumn{1}{|c|}{ Country } & Model & R-square & F - statistic * \\
\hline Norway & $\mathrm{P}_{\mathrm{t}}=\begin{array}{c}9.01-0.79 \mathrm{I}_{\mathrm{t}}-0.45 \mathrm{O}_{\mathrm{t}} \\
(20.29)(-10.60)(-3.08)\end{array}$ & 0.56 & 0.02 \\
\hline Mexico & $\mathrm{P}_{\mathrm{t}}=8.78+0.003 \mathrm{I}_{\mathrm{t}}-0.29 \mathrm{O}_{\mathrm{t}}$ & \\
& $(11.15)(0.03)(-1.20)$ & 0.57 & 60.98 \\
\hline Venezuela & $\mathrm{P}_{\mathrm{t}}=18.37-1.90 \mathrm{I}_{\mathrm{t}}-1.36 \mathrm{O}_{\mathrm{t}}$ & \\
& $\mathrm{P}_{\mathrm{t}}=3.88+1.40 \mathrm{I}_{\mathrm{t}}-0.31 \mathrm{O}_{\mathrm{t}}$ & 0.48 & 43.58 \\
\hline Oman & $(6.57)(9.21)(-1.63)$ & & \\
& & & \\
\hline
\end{tabular}

The figures in parenthesis are the t-statistics.

* The critical value at the 5 percent level for $\mathrm{F}(2,93)=3.15$

The result for Norway shows that fifty six percent of the variation in the stock market price index is explained by the variation in the interest rate and the oil prices variables. Both coefficients of the two independent variables are statistically significant at the five percent level, as indicated by the t-statistics values. Furthermore, the overall regression result is highly significant as indicated by the F-statistic, see Table 6. But in the case of Mexico, both the interest rate and the oil prices variables are statistically insignificant and the F-statistic indicates that the model is not appropriately specified. The regression analysis for Venezuela shows that same finding as in Norway. But for Oman, while the coefficient of interest rate variable is highly significant, the coefficient for the oil prices variable is only significant at the 10 percent level. Are the results for Norway, Venezuela and Oman, in Table 3, sufficient to decide that the three nonstationary variables are cointegrated to form a long-term statistical relationship? The answer is no. We need to first determine if the residual terms of the above regression analyses are stationary in order to confirm if the variables are cointegrated. Figure 4 shows plots of the residual terms from the above four regression models. 
Figure 4

Residuals from Regression Analysis
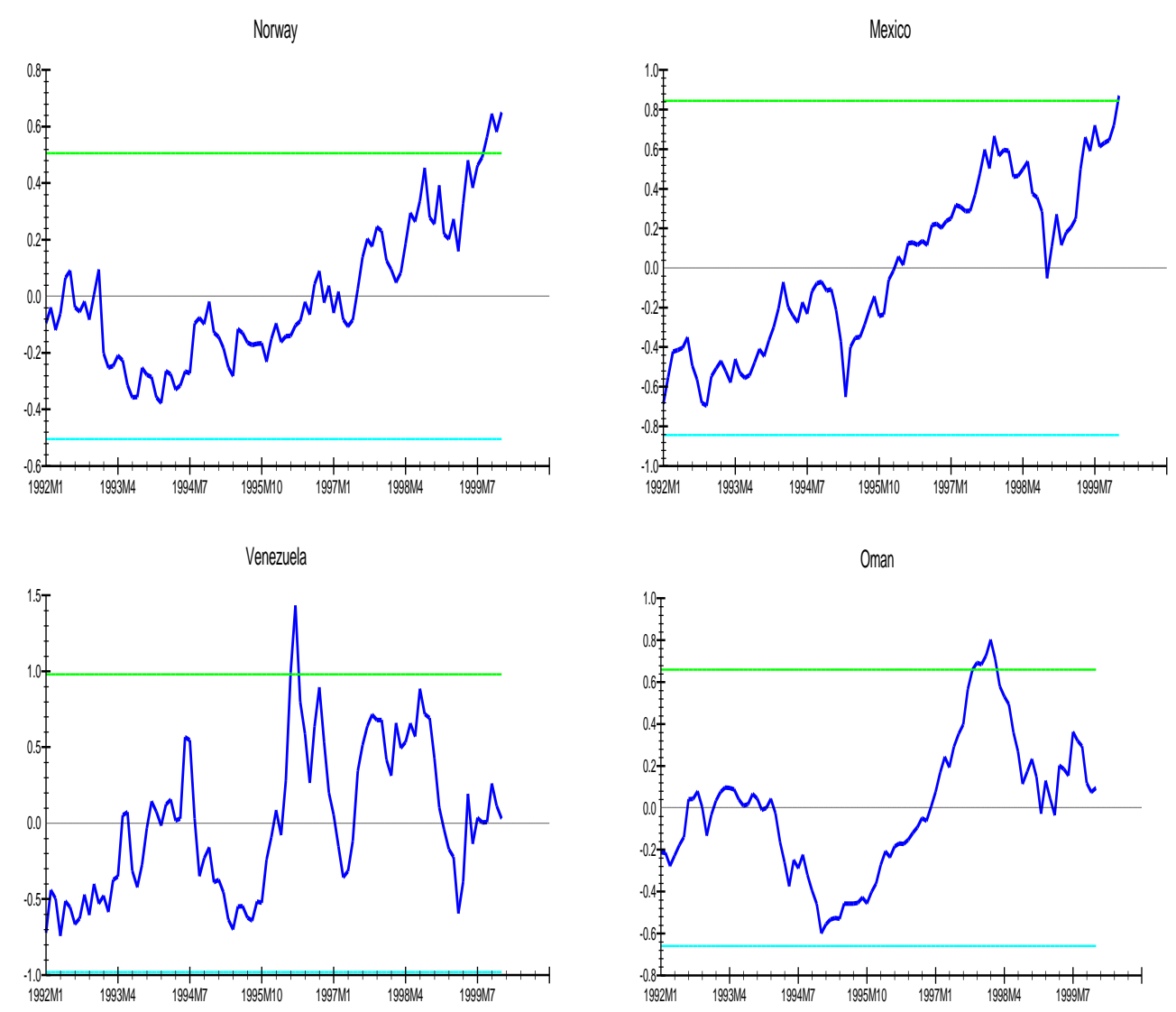

Table 7

The Unit Root Tests for the Residual Terms From the Predictability tests: January1992-December 1999.

\begin{tabular}{|l|c|}
\hline \multicolumn{1}{|c|}{ Country } & ADF $*$ \\
\hline Norway & -0.09 \\
\hline Mexico & -0.41 \\
\hline Venezuela & -3.16 \\
\hline Oman & -1.21 \\
\hline
\end{tabular}

* The critical value for the ADF statistic $=-3.85$

The plots of the residual terms for Norway and Mexico, in Figure 4, show an upward trend which indicates nonstationarity of these two residual terms. But for Venezuela, the residuals fluctuate around their zero mean which points to the likelihood of stationarity. Finally, the residuals for Oman show an upward trend in the period from 1994 to the first half of 1998. The ADF unit root tests provide another insight to whether the residual terms for Venezuela and Oman are stationary or not. If the residual term (u t), in Equation (5) is stationary, then the null-hypothesis of nocointegration can be rejected based on the augmented DickeyFuller unit root test of the residuals (see Table 7). A rejection of the null-hypothesis means that the nonstationary variables in Equation (1) are cointegrated.

The ADF unit root test of the residuals from the previous regressions, in Table 4, shows that the estimated value for Norway, Mexico and Oman are less than their critical values which means that the residual terms for these three countries are not stationary. That is, the null hypothesis of no cointegration cannot be rejected and the regression equations for Norway, Mexico and Oman are spurious. In other words, the interest rate and the oil prices variables do not have any predictive power for the stock market price indexes during this period of analysis. On the other hand, the ADF unit root test of the residual term for Venezuela reveals that it is statistically significant at the ten percent level. This means the stock market price index in Venezuela is cointegrated with the interest rate and the oil prices variables to form a long-term statistical relationship; hence they have a predictive power in determining share prices. 


\section{Conclusions And Implications For Future Research}

The empirical results from tests of return predictability for Norway, Mexico and Oman show that interest rate and oil prices variables do not have significant power of prediction because they are not cointegrated, hence they are spurious regressions. Whereas, the empirical result for Venezuela shows that interest rate and oil prices variables are weakly significant in determining the long-run statistical equilibrium relationship of listed share prices. While the countries included in this study are all net oil exporting countries, that similarity did not prevent mixed results with cointegration models.

Godbout and van Norden (1997) checked the validity of conclusions from three types of studies in international finance: (1)cointegration and prediction of nominal spot exchange rates (2) long-run validity of the monetary model of exchange rate determination (3) common stochastic trends in the international stock market. Their method for checking the validity of conclusions was to simulate the data under the null hypothesis of no integration. They found that there could be considerable size distortion even in samples of 1,000 observations. While correction factors reduced the distortions, other corrections were necessary.

Berben and van Dijk (1998) asked: "Does the absence of cointegration explain the typical findings in long horizon regressions? Their answer was: yes. Over long time horizons, as the horizon increases one usually finds increases in the absolute values of: (1) point estimates of the regression parameter (2) the associated t-statistic to test its significance (3) the regression r-squared. By assuming that cointegration holds, one is assuming that the tstatistic is asymptotically Gaussian distributed at all horizons. If, instead, one regards a long horizon regression as a conditional error-correction model, then there could be mixtures of Gaussian and Dickey-Fuller type distributions.

Gerdtham and Löthgren (1998) investigated the possible cointegration of health expenditure and GDP, using 36 years of data $(1960-1995)$ from 19 OECD countries. This approach provided an opportunity to analyze country-by-country and panel results using the Johansen multivariate likelihood-based inference and the Larsson cointegration panel rank test for heterogeneous panel models. Individual country-by-country results were mixed. The researchers reviewed some other studies with mixed results. They noted that if the data series are trending then one should include a time trend. They concluded that their results could be sensitive to: (1) the use of variables in log-linear form (2) the use of a bivariate vector autoregressive model (3) the inclusion of additional variables.

Granger and Yoon (2002) concluded that it is possible for data series to have hidden cointegration when data series are not cointegrated in the conventional sense. Hidden cointegration is an example of nonlinear cointegration. They reported that the federal funds rate and the ten-year Treasury bill rate possessed hidden cointegration during a sample period.

While the early claims were that cointegration was needed to deal with the problem of spurious regressions, a large number of international studies with mixed results have shown the need to review the conclusions and methodologies of the earlier cointegration studies. 


\section{References}

1. Al-Shanfari, H. (2001), Testing the Arbitrage Pricing Theory in the Global Context, University of Strathclyde, Scotland, Unpublished Doctorate Thesis.

2. Berben, Robert-Paul and Dick van Dijk (1998), "Does the Absence of Cointegration Explain the Typical Findings in Long Horizon Regressions?", April 6, 1998.

3. Campbell, J. and R. Shiller (1987), "Cointegration and Tests of Present Value Models", Journal of Political Economy, 95, 1062-1088.

4. Clare, A. and S. Thomas (1992), "The Predictability of International Bond and Stock Returns", Economic Letters, 40, 105-112.

5. Clare A, R. Priestley and S. Thomas (1997), "Stock Return Predictability or Mismeasured Risk?” Applied Financial Economics, 7, 6, 679-688.

6. Dickey, D and W. Fuller (1979), "Distribution of the Estimators for Autoregressive Time Series with a Unit Root", Journal of the American Statistical Association, 74, 427-31.

7. Dickey, D and W. Fuller (1981), "Likelihood Ratio Statistics for Autoregressive Time Series with a Unit Root", Econometrica, 49, 1057-72.

8. Engle, R. and C. Granger (1991), Long-run Economic Relationships: Reading in Cointegration, Oxford University Press.

9. Fama, E., (1970), "Efficient Capital Markets: A Review of Theory and Empirical Work", Journal of Finance, 25 (2), 385-417.

10. Fama, E. (1991),“Efficient Capital Markets: II”, Journal of Finance, 46 (5), 1575-1617.

11. Ferson, W. and C. Harvey (1993), "The Risk and Predictability of International Equity Returns", The Review of Financial Studies, 6, 3, 527-566.

12. Ferson, W. and C. Harvey (1994), "Sources of Risk and Expected Returns in Global Equity Markets", Journal of Banking and Finance, 18, 775-803.

13. Ferson, W. and C. Harvey (1998), "Fundamental Determinants of National Equity Market Returns; A Perspective on Conditional Asset Pricing", Journal of Banking and Finance, 21, 1625-1665.

14. Gerdtham, Ulf-G. and Mickael Löthgren (1998), "International Health Expenditure and GDP: New Multivariate Cointegration Panel Data Results", Working Paper Series in Economics and Finance, Number 258, Stockholm School of Economics, September 21, 1998.

15. Godbout, Marie-Josée and Simon van Norden (1997), "Reconsidering Cointegration in International Finance: Three Case Studies of Size Distortion in Finite Samples", Bank of Canada Working Paper 97-1, January 1997, Bank of Canada, 234 Wellington Street, Ottawa, ON, Canada K1A 0G9.

16. Granger, C.W.J. (1981), "Some Properties of Time Series Data and Their Use in Econometric Model Specification", Journal of Econometrics, 121 - 130.

17. Granger, C.W.J. and Gawon Yoon (2002), "Hidden Cointegration", Discussion Paper 2002-2, January 2002, Department of Economics, University of California, San Diego.

18. Harvey, C. (1995), "Predictable Risk and Returns in Emerging Markets", Review of Financial Studies, 8 (3), 773-816.

19. Harris, R. (1995), Using Co-Integration Analysis in Econometric Modelling, Prentice Hall.

20. MacDonald, R. (1994), "Stock Prices and Excessive Volatility: Some Evidence for the FT Ordinary Share Index", Journal of Business Finance and Accounting, 21, 1, 65-76.

21. MacDonald, R. and D. Power (1994), "An Alternative Test of Stock Market Efficiency: An Analysis of UK Share Price Data", British Review of Economic Issues, 16, 38, 33-54.

22. Shiller, R. (1997), Market Volatility, MIT Press.

23. Shiller, R. (1981), "Do Stock Prices Move Too Much to be Justified by Subsequent Changes in Dividends", American Economic Review, 71, 3, 421-436. 